\title{
Article
}

\section{Co-Management of Protected Areas: A Governance System Analysis of Vatnajökull National Park, Iceland}

\author{
Jon Geir Petursson ${ }^{1, *(1)}$ and Dadi Mar Kristofersson ${ }^{2}$ \\ 1 Environment and Natural Resources, Faculties of Life and Environmental Sciences, and Sociology, \\ Anthropology and Folkloristics, University of Iceland, 102 Reykjavik, Iceland \\ 2 Faculty of Economics, University of Iceland, 102 Reykjavik, Iceland; dmk@hi.is \\ * Correspondence: jgp@hi.is
}

check for

updates

Citation: Petursson, J.G.;

Kristofersson, D.M. Co-Management

of Protected Areas: A Governance

System Analysis of Vatnajökull

National Park, Iceland. Land 2021, 10,

681. https://doi.org/10.3390/

land10070681

\section{Academic Editors: Mónica}

de Castro-Pardo, Joao C. Azevedo

and Pascual Fernández

Received: 1 June 2021

Accepted: 25 June 2021

Published: 28 June 2021

Publisher's Note: MDPI stays neutral with regard to jurisdictional claims in published maps and institutional affiliations.

Copyright: (c) 2021 by the authors. Licensee MDPI, Basel, Switzerland. This article is an open access article distributed under the terms and conditions of the Creative Commons Attribution (CC BY) license (https:/ / creativecommons.org/licenses/by/ $4.0 /)$.

\begin{abstract}
Land allocated to protected areas (PA) is expanding as are expectations about the services these areas deliver. There is a need to advance knowledge on PA governance systems, like comanagement, recognising that there is no "one-size-fits-all" solution. We analyse the co-management governance system and performance of Vatnajökull National Park (VNP), Iceland. We adapt an analytical framework from the literature on environmental governance and analyse its governance system, hence actor roles, institutional arrangements and interactions. Our findings illustrate that the co-management structure was an outcome of political negotiations and a response to the lack of legitimacy of its predecessors; resulting in a tailor-made governance system set out in parkspecific legislation. Although the performance is quite positive, being adaptive to changes, inclusive, promoting rural development and an appreciated facilitator of devolution and power-sharing, it has come with challenges. It has encountered problems delineating responsibilities among its actors, causing conflict and confusion; in settling conflicting localised issues close to local stakeholders, there have been capacity issues. We argue that the VNP co-management system is fit for its purpose, aligned with Icelandic land-use governance structures but in need of systematic improvements. There are important lessons as Iceland seeks to expand its PA estate and beyond, since the global community is setting ambitious policy goals to expand site-based conservation.
\end{abstract}

Keywords: co-management; protected areas; rural development; governance system; legitimacy; Vatnajökull National Park; Iceland

\section{Introduction}

Land designated as protected areas (PA) has greatly increased globally during the past decades, with even more ambitious targets on the horizon. It is seen as a key instrument for the conservation of nature, with most nation states currently expanding their PA estates [1,2]. Concurrently, expectations about the delivery of multiple services from such areas, beyond purely conservation objectives, has evolved and expanded [3]. This requires suitable and effective governance approaches to PAs that can accommodate the different localities and socio-economic settings to operate within [4,5]. Co-management is an approach to govern natural resources that has gained wide attention, acting as a compromise between top-down and bottom-up approaches [6]. It can be defined as multilevel resource governance when the central government shares power and responsibility with other actors, typically including resources users, local government and often also the private sector and civil society [7]. The proponents of the co-management paradigm claim that it entails options for more socially inclusive and effective approaches, having promoted the approach as a strategy to mitigate conflicts, promote local rights, equity, legitimacy, and sustainability [8]. This may further resolve constraints between different levels of government, generating increased accountability upwards and increased legitimacy downwards $[9,10]$. Different forms of co-management have been applied across 
many natural resource contexts worldwide, like in fisheries, grazing, forestry, wildlife and PAs [11,12].

This study focuses on the application of co-management in the context of PA governance. PAs are important parts of national strategies to govern biodiversity and carbon resources, landscapes and multiple other environmental services, encompassing now more than $15 \%$ of the global terrestrial area [3]. PA governance has been subject to multiple challenges. For a long time, the key approach was based on top-down centralised models, often described by the metaphor of a "fortress" approach to governance [13]. This type of traditional top-down governance has been criticised for not delivering legitimate and efficient conservation and has frequently been a source of multiple social conflicts. There has therefore been an appeal for alternative governance strategies [14]. PA governance has been evolving over the past few decades towards more enabling contexts for conservation, seeking more socially inclusive and legitimate governance where co-management has become an influential approach $[15,16]$, often as a part of national decentralisation agendas [17]. This has manifested in alternative strategies including co-management and direct community conservation strategies, seeing transfer of mandates and power-sharing agreements between actors at different governance levels [18]. Co-management has emerged from these transitions as an influential narrative of joint decision-making between central and local level actors, distinguished by the presence of some level of power-sharing and partnerships $[6,16]$.

Simultaneously there has been a transition in expectations about the delivery of PAs and governance systems to accommodate that. For a long period in economic terms, PA were looked upon as "economic black holes" in the otherwise productive rural agricultural landscapes, including in Iceland [19]. The initial view was that such areas were mainly supposed to deliver strict conservation, leaving the interest in their existence mainly to conservationists and philanthropists outside of the economic rational. This economical notion has, however, been changing, with increased focus on the broad delivery of ecosystem services to society at large, perhaps most notably tourism, rural development and public goods such as carbon and water [3]. Concurrently, PAs are becoming increasingly recognised as important for the growing nature-based tourism sector, worldwide [20].

Summing up responses to these PA transitions has created a widespread call for alternative and innovative governance models that can meet the challenges of multiple delivery of both social and ecological criteria [21]. Co-management is there seen as one key alternative approach, providing a model for more inclusive governance and a vehicle for delivery of multiple ecosystem services.

The co-management approach has, however, been challenging to implement. Although current political trends tend to promote the approach, empirical findings on performance remain ambiguous about the degree of success and many studies have cautioned against seeing it as a panacea for advancing the legitimacy of governance [22,23]. It is also important that when instituting a co-management system, no standard or blueprint design exists, but rather it should be viewed as a call for innovative and tailor-made institutional solutions since local environment conditions, social settings, contexts and capacities vary $[3,23,24]$. These issues are also interdependent. Therefore, it is the design of the co-management system that will largely shape the governance outcomes.

Iceland constitutes a good case for the study of some of those PA transitions. Its protected area estate has been developing for a long period of time, currently encompassing ca. 1/4 of its lands under formal protection, including the large Vatnajökull National Park (VNP) [25]. The expectations towards delivery of services from the PAs have been changing. In addition to conserving nature, it is recognised for its capacity with regards to naturebased tourism as a driver of rural development.

This study aims to contribute to the debate on how to design inclusive governance systems for PAs. Its main objective is to advance the knowledge about the design and performance of the co-management approach to govern PAs. It is, therefore, not the scope of this study to assess directly the ecological conservation outcomes in the park. We develop 
an analytical framework to analyse the design and performance of a co-management resources governance system for PAs, using the case of VNP in Iceland, established in 2007 with a co-management approach to governance.

Our main research questions are as follows:

- How can a co-management governance system be designed for a large national park?

- What have been the main challenges impacting the performance of the co-management governance system?

- What are the key policy implications and how can they inform park governance and rural development?

\section{Materials and Methods}

\subsection{Governance System Analytical Framework}

This study is conceptually based on a governance system analysis framework to analyse the design and performance of PA co-management and related processes. It has theoretical underpinnings in institutional theory and elaborates its analytical framework from theories about the governance of environmental resources [26-28].

We understand co-management as a specific type of natural resources governance system, and for this study, as an approach to govern protected areas. Well-defined frameworks are available for the analysis of such governance systems to investigate their various components and interrelationships [29,30]. We employ a modified version of such a framework to guide our analyses of the co-management governance system in VNP (Figure 1). Importantly, there is no blueprint for the design of such co-management governance systems. Additionally, policy options are usually narrowed down as such systems do not emerge in a vacuum but are frequently shaped and re-shaped by historical institutional processes and legacies [31].

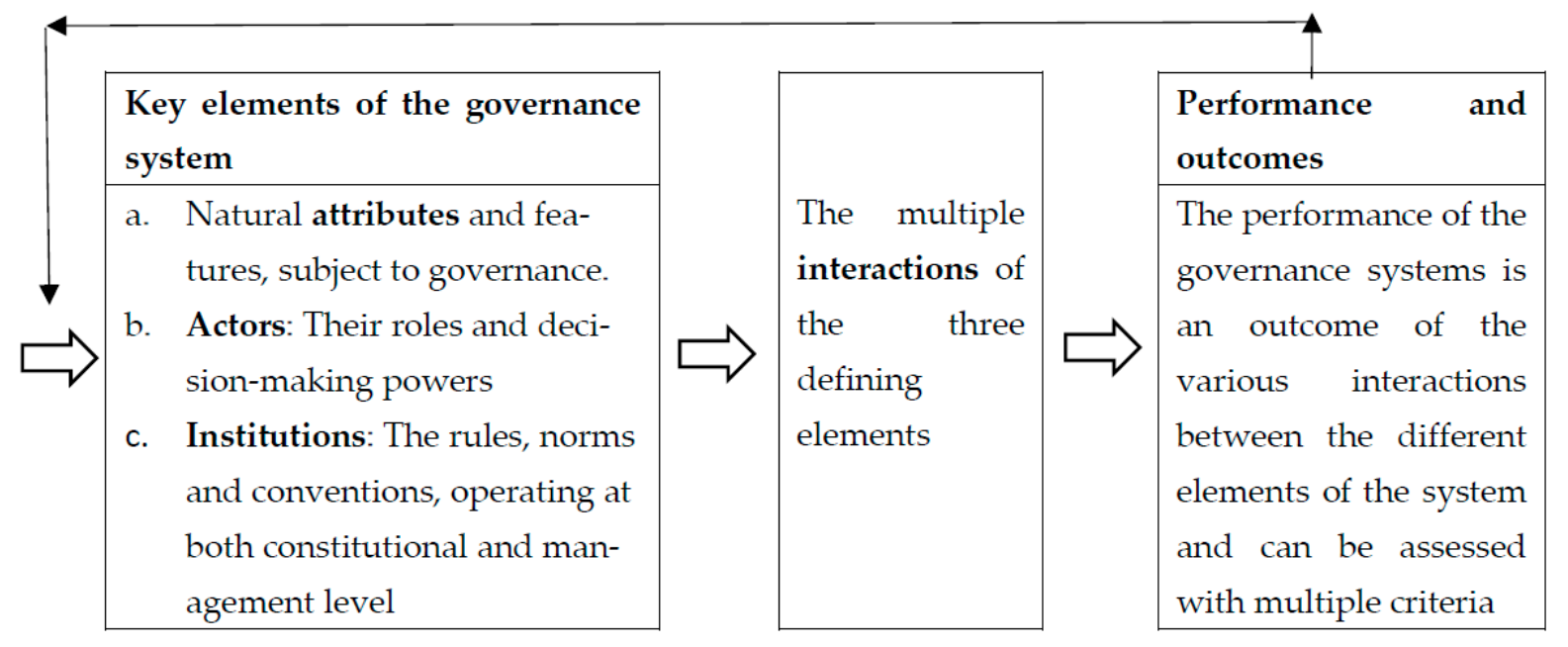

Figure 1. A natural resources governance system and its analytical elements (Adopted from Vatn, 2015).

The governance system framework is built on an understanding of its three main components and their interactions.

First, institutions are central when examining how humans relate to the environment and all humanly using natural resources can be understood to be embedded in complex, social-ecological systems [29]. Institutions in this context provide the set of rules, norms and conventions that guide and are being guided by, the human interactions with the environment [32]. Institutions are different from the organisations that constitute the actors that make policies, take decisions or are affected by decisions. Institutions are not static but subject to change and evolution [30]. Importantly, co-management can be viewed either as a model for new PAs or as an institutional change alternative to already existing PAs that have been governed under different approaches. The study of any governance system is 
therefore influenced by the history and legacy of the older systems, its power relations and conflict levels [31].

Second, the actors are those that have a role in the given governance system. They can broadly be differentiated according to capacities in the civil society, constituting economic or administrative actors that further operate at different levels. Core analytical issues concern actor agencies as defined by their power and resources, rights and responsibilities, and how these facets are derived from different sources. As power-sharing is an implicit objective of co-management, who gets what power and how actors exercise their power become an important analytical issue $[11,33]$. Power is, however, a highly contested term in all social analysis [34]. We follow the argument made by Giddens [35] that "power is the capacity to achieve outcomes", with the notion that to have resources is one thing but to use them and be effective is another [34].

Third, there are the attributes of the natural resources at stake. No national parks have the same natural resources and nor their socio-ecological relations are the same. This calls for an institutional framework that fits well with the physical attributes of the natural resources at stake [31].

\subsection{Assessing Performance of a Governance System}

Governance performance can be assessed in different ways, according to different criteria and at multiple levels [30]. For our study of the performance of the governance system, we employ two important criteria: legitimacy, both at the input and output levels and institutional fitness (Table 1).

Table 1. Criteria for the co-management governance system performance assessment.

\begin{tabular}{|c|c|c|}
\hline \multicolumn{2}{|c|}{ Analytical Criteria } & \multirow{2}{*}{$\begin{array}{c}\text { Relative to Park Governance } \\
\text { Factors that shaped the park creation. } \\
\text { Focus on participation and representation. } \\
\text { Factors related to park operation. Focus on } \\
\text { accountability and performance. }\end{array}$} \\
\hline Legitimacy & $\begin{array}{c}\text { Input level } \\
\text { Output level }\end{array}$ & \\
\hline Institutional fitness & Interplay & $\begin{array}{l}\text { The fitness of the governance system to the } \\
\text { physical attributes. Concerns mainly } \\
\text { spatial fit, but is to a lesser degree temporal } \\
\text { and functional. } \\
\text { The interplay with other institutions at } \\
\text { both horizonal and vertical levels. }\end{array}$ \\
\hline
\end{tabular}

Legitimacy is an important analytical criterion for the evaluation of a governance system and its performance, understood here as something that goes beyond legality to incorporate justified authority [36]. We differentiate our understanding of legitimacy at the input-output level. At the input level, analysis focuses especially on the acceptability of decisions, participation and representation, whereas output legitimacy investigates governance outcomes and effectiveness [30].

PA establishment is essentially an institutional exercise, determining spatial demarcations of land and the establishment of management rules. Institutional fit is a concept covering the relationships in a governance system between involved institutions and the biophysical systems [31]. It refers to how well the institutional arrangements match the defining features of the perceived biophysical problems they address [37]. PA institutions, however, do not operate in a vacuum but are subject to multiple interplays with other land-use-related institutions, both at horizonal and vertical levels [38]. Therefore, how institutions fit and their interplay represent important evaluation criteria of PAs and their performance. 


\subsection{The Study Site and Its Governance Context}

\subsubsection{The Case: Vatnajökull National Park}

This study takes the case of Vatnajökull National Park (VNP) that was created with legislation passing the Icelandic Parliament in 2007 that set foundation for issuing a by-law, that formally was enacted by the Minster in the 2008, formally establishing the park [39]. VNP was established via the merging of two existing national parks, Skaftafell NP founded in 1967 and Jökulsárgljúfur NP founded in 1973, and the addition of a large area encompassing the whole of the Vatnajökull Glacier and some of its surrounding landscapes. Since its establishment, it has gradually been expanded to its current size of approximately $14,700 \mathrm{~km}^{2}$, constituting around $14 \%$ of Iceland's total land area (Figure 2). It is currently the largest national park in Europe, outside of Russia, and is classified as Category II with embedded Category Ib and VI areas according to the IUCN categorisation [39].
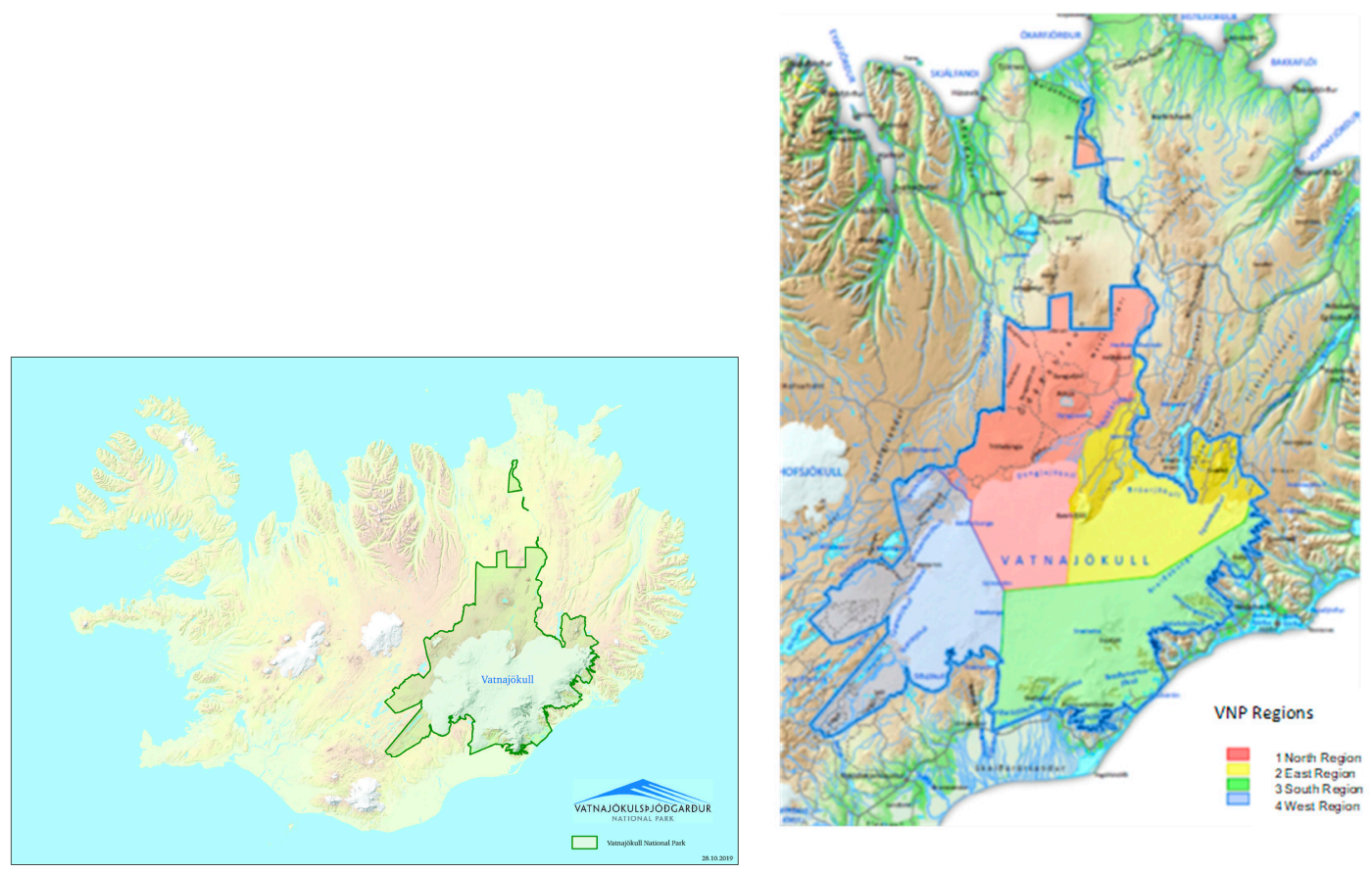

Figure 2. Maps of Vatnajökull National Park in Iceland and its four administrative regions (Source: Vatnajökull NP).

VNP includes the Vatnajökull Glacier ice cap that covers around more than half of the park. It represents an example of the shaping forces of nature, including the dividing tectonic plates of North America and Eurasia, and associated geological processes. Due to its globally unique geographical features, with volcanic activity and glacial forces occurring simultaneously, the park demonstrates the dynamic forces of nature, characteristics which led to it becoming a UNESCO World Heritage Site in 2019. This is well described in the foundation document for the UNESCO inscription [39].

The park exclusively includes uninhabited areas with no permanent human settlement within its boundaries in recent history. Some of the surrounding landscapes next to the park boundary are settled, especially in the southern part.

Tourism is by-far the biggest economic activity in the park and of significant importance at multiple levels. Visitor number in VNP have been high, with some of its most popular sites receiving around 1 million annual visitors in 2019.

\subsubsection{Some Governance Factors Related to Area-Based Conservation in Iceland}

PAs are a significant land-use category in Iceland with about $26.5 \%$ of the country area under legal protection in around 120 individual units [40]. The first protected area was established by law in 1930 but the largest area additions have occurred during the past 
few decades, especially VNP in 2007 [25]. We identify some land governance factors that matter and shape area-based conservation considerations in the country, especially with a focus on the central highlands.

Iceland is quite sparsely populated with around 360,000 inhabitants on $103,000 \mathrm{~km}^{2}$ land area, equating to population density of only 3.5 person $/ \mathrm{km}^{2}$. Of these, around $60 \%$ of the population resides in the capital area and its immediate surroundings. Vast tracts of the central regions are uninhabited due to harsh conditions. Only around $1.2 \%$ of the land is under cultivation agriculture, either hayfields or croplands, although most other lands outside cultivation are subject to seasonal sheep grazing, one of the most common types of farming in Iceland. Nature-based tourism, which much occurs in PAs, expanded greatly from 2010-2019 and rose to become the country's biggest export earner and major rural development driver [41]. The economic potential of PAs as a land-use category are therefore increasingly recognised [42].

The country has two levels of government, central and local at the municipal level, the latter is currently formed of 69 units. Most aspects of general nature conservation and natural resource governance are the mandate of the central government, and the direct role of local governments is relatively limited. However, local governments, do have substantial power to influence most conservation and natural resources policies within their constituencies, due to their responsibility for spatial planning. In the context of PA establishment, the central government has never established a PA without seeking consent from the respective local government, regardless of its land tenure.

PAs are established according to two pathways in Iceland [25]. Most commonly, protected areas are designated according to the Nature Conservation Act. The act allows for different categories of PAs, including the designation of national parks. PAs established under the Nature Conservation Act allow the formation of consultation committees but do not, however, facilitate power-sharing co-management governance. However, some larger PAs have been established under site-specific legislation that can allow for a more tailor-made, flexible approach to governance.

Although a well-developed economy, the property rights concerning most lands in the central highlands have long been subject to ownership disputes, deadlocking land-use decisions in the region. The government initiated a major land reform process in 1998 with the establishment of a special governmental committee (Óbyggðanefnd) aiming to resolve these issues [43]. This has resulted in a protracted legal process, still ongoing, where most of the lands in the central highlands have to date been declared public lands (Pjóðlendur). This process has caused multiple conflicts but has now completed clarifying land-rights in most of the central highlands. This has had implications for PA considerations and any other land-use decisions as this has clarified land rights and responsibilities in the region.

The institutional attributes of the public lands also matter. According to Icelandic law, the management of public lands is subject to collaboration between the two tiers of government, the central and local. The overall authority is in the hands of the Prime Minister's office. In addition, certain groups of farmers are formally granted usufruct rights to some resources like grazing and fishing, commonly based on historical rights. PAs on public lands therefore already include co-management aspects concerning the respective roles of central and local government, and the usufruct rights of individual holders to some resources.

\subsection{Data Sources}

The qualitative data for this study are based on multiple sources, collected in phases from 2013 to date. This long period of data gathering has enabled a longitudinal analysis of the co-management system and how its governance has progressed. First, we conducted a systematic analysis of secondary data, for example, on the processes around the park's establishment, and its natural and cultural attributes. There is a major report on the park's unique natural attributes that was produced as a part of the UNESCO World Heritage Site application, leading to its inscription on the list [39]. We would also like to note some 
unpublished master's thesis from the University of Iceland on different aspects of VNP establishment $[44,45]$. Second, we collected multiple data as a part of a study commissioned by the Ministry for the Environment and Natural Resources in 2013, as members of an expert committee set up to formally assess the park's performance [46]. A web-based semistructured questionnaire was sent to key actors in the VNP governance systems, asking about different aspects of the park governance (see its structure in Supplementary Material). We also conducted focus group meetings in the park's four administrative regions (in Skútustaðir (north); Egilsstaðir (east); Smyrlabjörg (south) and Kirkjubæjarklaustur (west)), organised with a structured discussion around selected questions and an open, more general discussion focusing on the current governance structures, perceptions and performance outcomes. The meetings were publicly announced and open to all. They were attended by a wide range of stakeholders, both local actors with a formal role in the co-management system, park staff and the general public. This was followed by in-depth interviews, conducted with a selected group of actors who have major responsibility for park governance. The third category of data derived from a series of interviews, beyond the 2013 assessment, was conducted with stakeholders in VNP management at all levels.

\section{Results and Discussion}

\subsection{Historical and Political Legacies Shaping VNP Approach to Governance}

There are multiple historical processes and political considerations that shaped the idea for the establishment of VNP and contributed and defined its approach to governance. Our interviews revealed that it was not merely an outcome of simple technical or rational, apolitical policy-making.

The driving forces behind the establishment of VNP are relatively well described, highlighting the dual perspectives of nature conservation and aspirations for rural development. They were also considerably influenced by the debate and trade-offs about the construction of the large Kárahnjúkar dam from 2003 to 2007 [39,44,45,47,48].

Our focus is, however, on the approach to governance selected and the role of comanagement in VNP. We can identify some processes that were a recurrent theme during our interviews, concurrently driving VNP's establishment and shaping its governance approach.

The debates and controversies around the hydro-electric development in Kárahnjúkar were frequently raised. An outcome of this debate was a double-sided decision on conservation and development, hence, to build the large dam and establish the large park. After that became clear, the interviewees observed that, concurrently with the tri-lateral negotiations between the central government, local governments and other stakeholders on the park establishment, is was evident that it would not be possible without adopting a governance model that would enable local level actors to have a direct stake in the park's governance, especially within the local governments. Nor was fully devolving the authority to govern the park to the local governments seen as an option, partly due to the large numbers of municipalities in Iceland. The local governments have, via their legal mandates in spatial planning over their respective constituencies, a veto right on the establishment of protected areas. It was therefore quickly recognised that some sort of co-management with shared powers needed to be the way forward.

During the period of the park's establishment, the Obyggðanefnd (wilderness committee) had clarified the ownership of most of the lands that were suggested for inclusion in VNP, and this paved the way for the park's establishment and its initial spatial demarcation. Some areas considered to be included in the park were left out due to unsettled land ownership disputes but were reserved for potential inclusion later. As the property rights regime for public lands is already subject to co-management between central and local governments, this was conducive with the park's co-management considerations.

Lastly, the two former national parks, Skaftafell, founded in 1967, and Jökulsárgljúfur, founded in 1973, that were merged into VNP had been governed according to a centralised, top down governance approach (Figure 3). It was claimed that the two parks had suffered 
from a lack of legitimacy in the view of local actors, and the parks and park decisionmaking was therefore seen as distanced from the local communities and not connected to local government decision-making. This fed into the discussion around VNP and the need for a strong local voice for more inclusive park governance. This voice was stronger in the northern than the southern region and manifested clearly in the year 2004, when a large step towards the establishment of VNP was taken by expanding Skaftafell NP in the south to the whole of the southern part of Vatnajökull Glacier (Figure 3).

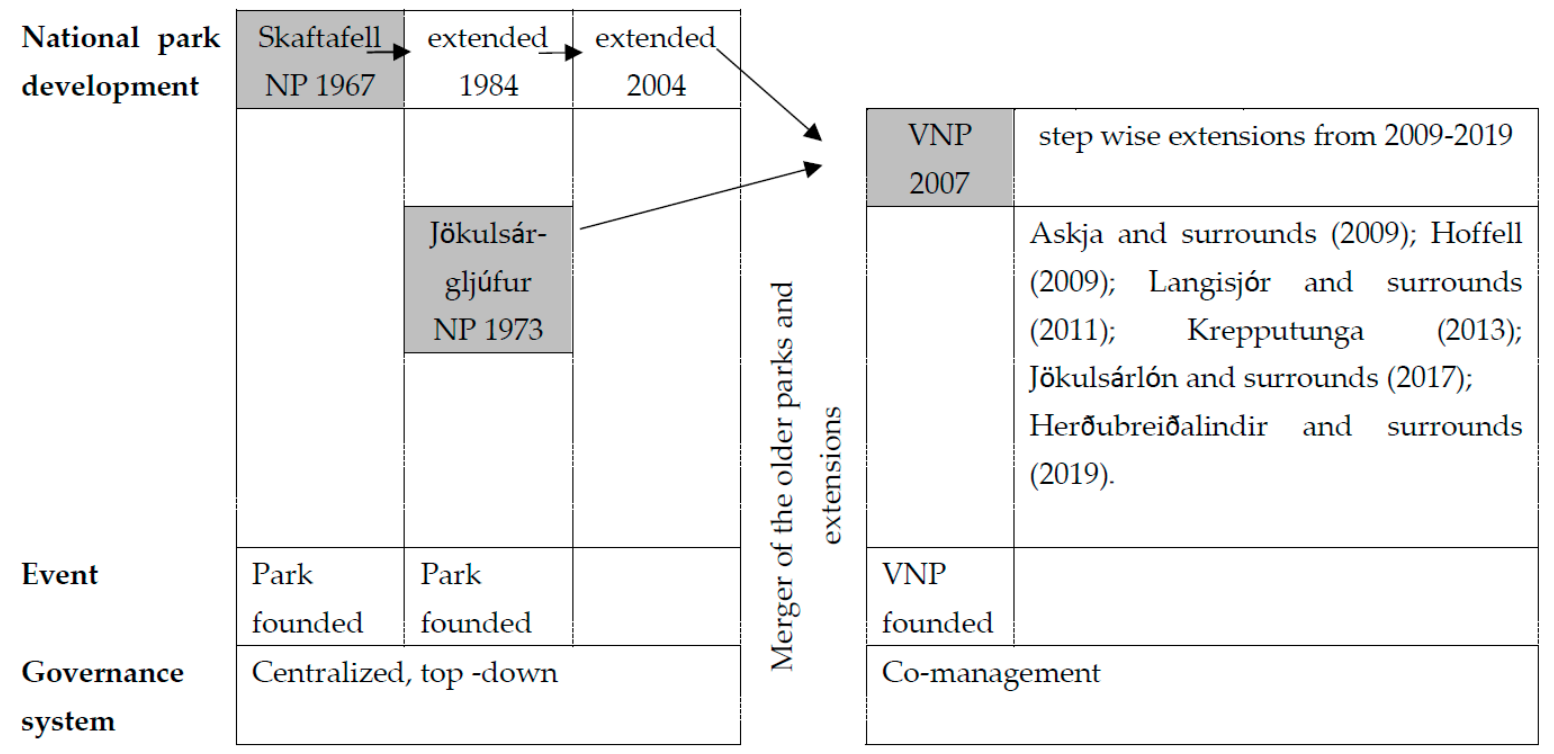

Figure 3. The development process of Vatnajökull National Park (VNP) and its predecessors.

According to our interviewees, these historical and political legacies jointly narrowed the policy options to materialise the central political will to establish the large VNP, closing down options to establish the park without sharing and devolving authority to local government actors. It was not a primary desire on the part of central government side at the outset of management discussions to share park governance responsibilities with others, however, this quickly became an unambiguous reality if the park was going to be established.

Once this became clear, the next task was designing a co-management system for the park that could be aligned with the general governance structures in Iceland, as no such legal framework or co-management system existed for PAs in the country.

We find that the process of establishing the park was aimed at designing an inclusive power-sharing governance system, generating a high degree of input legitimacy, which still has an impact on how the park is perceived today. This was manifested by all local governments in the park by their willingness to formally sign-up to the park's establishment, prior to the law passing through the Icelandic Parliament in 2007 which created the right to establish the park with a co-management approach to governance.

\subsection{Institutions for Park Co-Management, Their Fit and Interplay}

An important feature of the institutional framework for VNP is that it was established through park-specific legislation and not under the general Nature Conservation Act as most other protected areas in the country. The Nature Conservation Act does not recognise co-management as a governance system for PAs. This park-specific legislation allowed for tailor-made institutional solutions to meet the expectations and political bargaining that unfolded during the preparations for the establishment of the park. Many features in the legislation helped to guide the formation of the institutions of the co-management governance system. The legislation outlines four key objectives of VNP that its management must address: 
(a) Conservation of nature and culture;

(b) Public access;

(c) Research and education;

(d) Regional economic development and sustainable use.

The park-specific legislation allowed for the establishment of an independent government agency that reports directly to the Minister. It has its own identity in the government annual budget and gives the VNP director full authority as a senior official. This, in essence, bypasses the Environment Agency, the agency that is otherwise responsible for PAs in the country. It also gives leverage to the devolved aspects of the co-management system, facilitating direct political attention and amplifying the possibility for park actors to lobby in the park interest.

The park-specific legislation enables the designing of roles for the various actors in the system and creation of multiple institutions related to park access and management. Many of these institutions are supposed to be designed and re-designed, bundled and delivered in the form of by-laws or strategic documents, and have direct backing in the park-specific legislation (Table 2).

Table 2. Main institutions, defining and guiding VNP governance.

\begin{tabular}{|c|c|c|c|}
\hline Lead Document & $\begin{array}{l}\text { Responsible } \\
\text { Actors }\end{array}$ & $\begin{array}{c}\text { Adoption and Amendment } \\
\text { Power }\end{array}$ & Key Contents \\
\hline Legislation & The Icelandic Parliament & By majority at the parliament & $\begin{array}{l}\text { Outlines the overall objectives } \\
\text { and the governance structure } \\
\text { including role and mandates of } \\
\text { key actors }\end{array}$ \\
\hline By-law & The Minister & $\begin{array}{l}\text { The minister can make changes, } \\
\text { however, usually following } \\
\text { consultation with the Park Board }\end{array}$ & $\begin{array}{l}\text { Defines the park spatial } \\
\text { boundaries. } \\
\text { Sets out key rules }\end{array}$ \\
\hline $\begin{array}{c}\text { Management Plan (stjórnunar og } \\
\text { verndaáætlun) }\end{array}$ & The Park Board & $\begin{array}{l}\text { The management plan is } \\
\text { produced by regional councils } \\
\text { and the Park Board. The Minister } \\
\text { signs and ratifies the Plan but his } \\
\text { options to make changes are } \\
\text { limited to issues that might } \\
\text { conflict the park legislation }\end{array}$ & $\begin{array}{l}\text { Give detailed account of how the } \\
\text { park is supposed to be governed, } \\
\text { sets out decisions on } \\
\text { infrastructure and access rules }\end{array}$ \\
\hline $\begin{array}{l}\text { Commercial activity policy } \\
\text { (atvinnustefna) }\end{array}$ & The Park Board & $\begin{array}{l}\text { Produced by the regional councils } \\
\text { and Park Board. Issued by the } \\
\text { Park Board }\end{array}$ & $\begin{array}{l}\text { Outlines VNP's policy on } \\
\text { commercial operations within the } \\
\text { park and instruments for their } \\
\text { governance }\end{array}$ \\
\hline $\begin{array}{l}\text { Other rules, norms and } \\
\text { conventions }\end{array}$ & $\begin{array}{c}\text { The regional councils, Park Board } \\
\text { and Director }\end{array}$ & \multicolumn{2}{|c|}{$\begin{array}{l}\text { Diverse Codes of conduct and Rules of procedures that apply to } \\
\text { different administrative units within the co-management system. } \\
\text { Amendment power by the respective units. }\end{array}$} \\
\hline
\end{tabular}

The institutional bundles guiding the park's management have different decisionmaking levels that are central to understanding the power-sharing arrangements and devolution aspirations. Besides the legislation and by-laws that are institutional bundles operating at the constitutional level, the lead document for park management is its management plan. The legally anchored management plan is supposed to be the VNP's main platform and basis for policy-making and decision-making, produced with a bottom up approach that is inclusive of both internal (among park actors) and external stakeholder participation. The management plan is central in coordination and leverage of policy directions and decisions taken by park actors on the regional committees and its governing Board. Including a great level of detail and subject to regular updates, it sets the direction that the Park's director and its employees are supposed to follow and execute. We find that this is important for the efficiency of the co-management approach and there was a consensus among the interviewees in the semi-structured interviews that this was well-suited for fulfilling decentralised decision-making, generating legitimacy concerning the VNP's operations. 
The large park is divided into four management regions, each with substantial autonomy. This was regarded as a necessity due to the very large size of the park, long distances and different regional perceptions towards the park. The regional boundaries follow the constituencies of the respective local governments: one local government in the southern region, two in the eastern, and three in the northern and western. The VNP's formal rules are uniform to all the regions but allow for considerable flexibility of application. This means that there can be considerable different regional priorities in VNP, which allows for regional identities to emerge, but further create a significant coordination challenges for the Park's Board, especially once it comes to allocating funding and budgets to the regions.

The institutions for park access and resource use are supposed to serve its multiple objectives of conservation, public access and economic development (Table 3). We found that the institutions were those mostly delivering their purpose effectivity, although there was evidence of some local disputes on resource access issues, which appeared to be driven by different actors values and interests than flaws in institutional properties.

Table 3. Main rules of access and resource use within the park.

\begin{tabular}{ccc}
\hline Resources Use & Main Rules of Access & Manifestation \\
General access and recreation & Allowed & $\begin{array}{c}\text { According to the Icelandic free right to } \\
\text { roam (almannaréttur), all individuals } \\
\text { are entitled to enter the park and } \\
\text { wander. }\end{array}$ \\
Sheep grazing & $\begin{array}{c}\text { Summer grazing is allowed for a } \\
\text { given set of pastures under } \\
\text { traditional uses }\end{array}$ & $\begin{array}{c}\text { Farmers have legally protected } \\
\text { long-term usufruct rights to grazing to } \\
\text { most lands within the park boundary. }\end{array}$ \\
Hunting: reindeer & $\begin{array}{c}\text { Allowed in defined areas } \\
\text { according to the national reindeer } \\
\text { hunting regime }\end{array}$ & $\begin{array}{c}\text { Hunting licences are allotted by } \\
\text { government annually. Some } \\
\text { no-hunting zones within the park. }\end{array}$ \\
\hline Hunting: birds & $\begin{array}{c}\text { Generally allowed } \\
\text { Prohibited in defined areas with } \\
\text { the park }\end{array}$ & $\begin{array}{c}\text { Subject to hunting licences issued by } \\
\text { the government. Some no-hunting } \\
\text { zones within the park. }\end{array}$ \\
\hline Non-commercial fishing & $\begin{array}{c}\text { Traditional rules prevail } \\
\text { * added with the legal amendments in 2016. }\end{array}$ & $\begin{array}{c}\text { Farmers groups keep the fishing } \\
\text { rights they had before the park. } \\
\text { Fishing licences. }\end{array}$ \\
\hline
\end{tabular}

There was, however, one considerable matter lacking in the initial legislation establishing co-management of VNP. Once the park legislation was ratified and its legal instrument to regulate access, it did not differentiate the general individual right to roam and commercial tourism access or concession management. When the foundations for the park were negotiated, tourism was a relatively small sector but grew exponentially in Iceland from 2007-2019, with the number of annual foreign visitors expanding from around 450.000 in 2007 to around 2 million in 2019 [49]. Some of the VNP's more popular sites have been receiving around 1 million annual visitors. This has been among the greatest challenges for the park governance system, as many of its sites include the most popular natural features that tourists in Iceland aim to see. Concurrently, this growth sparked multiple economic opportunities for the neighbouring communities. The park's initial institutional framework simply lacked the necessary measures to regulate and guide commercial tourism, mitigating pressures and congestions. In 2013, an expert committee was founded to assess the VNP's performance, which was permitted by a clause in the establishment legislation from 2007 that requested reassessment of the co-management system. After a thorough study, the committee put forward recommendations that led to an amendment of the park legislation in 2015, establishing clauses of licencing for commercial tourism access. This change ensured that the institutional framework could regulate commercial tourism, occur- 
ring alongside a policy on commercial tourism, by-law and a set of contract and concession templates and rules. In this sense, the VNP's co-management governance system was quite responsive to an emerging challenge and capable of adapting. We find this to be a great strength of the system and an indicator of flexibility and responsiveness, as most land-use institutions in Iceland were badly prepared to handle the exponential increase in tourism. The pro-active approach by VNP has actually served as a model for other PAs in Iceland.

Once we assess the co-management system from the perspective of institutional fit, we find that the park-specific legislation and formal institutional framework that it shapes are well-fitting with the natural resources it is supposed to govern. Since its establishment, VNP has been subject to major extensions that have proven successful and embedded in the co-management institutions (Figure 3). Some issues of spatial misfit were raised in our interviews concerning the topic of landscape connectivity, mainly on the need to connect some of the shaping forces of nature in the park, such as lava field and glacier rivers that emanate from the park and perhaps should be a part of the park.

We identify, however, some challenges in institutional interplay, both within the VNP's governance system and with other institutions dealing with land-use issues that have both proven to be strengths and weaknesses of the co-management model.

The forces of vertical institutional interplay are evident in the provisions in the VNP's legislation that override the spatial planning mandate of the local governments and the role of the Prime Minister's Office in the management of public lands. This has truly been a seminal issue in leveraging the management plan of the park, giving it the status of the lead document for land-use decision-making within the park. Assessing vertical interplay within the park, the system has in general been efficient in coordinating the vertical interaction between the hierarchy of the bundles of institutions for its governance, mainly between the provisions of the legislation, by-laws and the management plan, all vested at different decision-making levels.

From the perspective of horizontal institutional interplay, we find it important that VNP is an autonomous government agency, separate from other PAs agencies in the country. This amplifies the VNP's status but on the other hand creates significant capacity concerns for its administration. We found this to be a common theme during our interviews, that VNP was lacking in administrate capacity on issues such as finance, law and technical capacity, which it needed from a government agency. This issue could be mitigated via a merger with other agencies or enhanced horizontal collaboration with other agencies.

Internally, the key forces of horizonal interplay have been apparent in the four autonomous regions, each with its unique features. The regional division was frequently mentioned as a great strength in bringing power down to local actors, but simultaneously is has created tensions around some issues, especially budget allocations and priorities in infrastructure development. The regions have also had to confront different legacies from the past, impacting the VPN's legitimacy, under different pressures from tourism and they have taken markedly different approaches on rural development opportunities. The perceptions among the local actors in the four regions towards the park are therefore quite different. This was made very clear during the stakeholder meetings in the different regions. This regional diversity is, however, not necessarily a weakness as there are many rural development success stories to tell, especially from the southern region that has been in the forefront at seizing opportunities related to the park, which has been well documented in other studies $[42,50]$. However, an important lesson is that although aspirations for rural development are articulated in the VNP's objectives, rural development does not come automatically. The VNP case illustrates clearly that it is dependent on the local actors to proactively seize the opportunities that the park provides. Under such circumstances, the park can become a great vehicle for regional economic development and job creation, as has been the case in its southern region.

Summing up, our analysis of the VNP's institutional framework reveals a quite solid co-management system to govern the large park, and the more recent changes have leveraged its operational capacity. We find, however, that the park-specific legislation, a 
key pillar in its co-management model, is partly a double-edged sword. It has been very beneficial for VNP, enabling a power-shared co-management structure around the park and leverage of its operative capacity. At the same time, it has proven to be very demanding to work with and requires political attention and willingness, capacity and resources not available for all PAs. It is therefore likely an unfeasible option for most co-management approaches except for very large parks that possess much prestige, like VNP truly does. As we find the co-management model conducive for efficient park management, able to cope and adapt to change, it should be more appropriate to establish a more general legislative framework that permits such governance approaches that could then be aligned and tailored to respective PAs, their attributes and services.

\subsection{The Actor Structure, Their Roles and Powers}

\subsubsection{The Actor Structure, Power and Membership}

We find that the institutional framework of the governance system is inclusive of many actors at different levels and it sets out and defines their different role and mandates. These actors represent both central government, local governments and civil society, however with different roles and power structures.

The co-management organisational structure of the park has essentially three key building blocks: the four Regional councils, the Park Board operating at the policy and decision-making level, and the Park Director and his team of staff, operating at a more executive level (Figure 4).

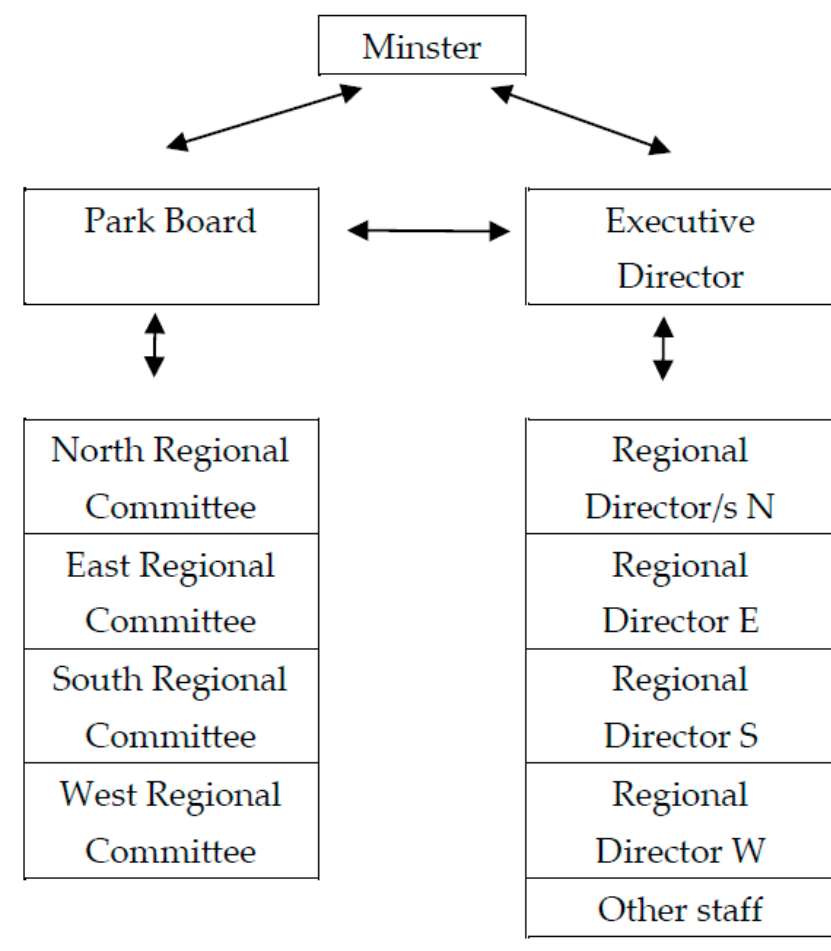

Policy mandate

Executive

mandate

Figure 4. The organisational structure of the co-management system of VNP.

At the central government level, VNP's administration falls within the remit of the Ministry for the Environment and Natural Resources. The official funding for the park comes from the government's central budget via this ministry. It has a defined Park Board with seven representatives, including two representatives from the central government, four from local governments and one from environmental civil society. Representatives 
from recreation and tourism civil society have observer status at the Park Board. The Minister is given the role to appoint the Chairman of the Board and the Vice-Chair. The Minster further appoints the Executive Director after recommendations from the Park Board, who holds the status of a public official. The regional Park directors are also state employees, under the supervision of the Executive Director. They are, however recruited, after recommendations from the respective regional councils.

Within each regional council, the local governments have three representatives, one of whom constitutes the chair. The respective local government chairs in the four regional councils are nominated as the four local government members on the Park Board. The local governments are therefore given substantial formal power in the actor structure in the legislation, having the majority of the votes on the Park Board with four representatives out of seven and the majority on the regional councils.

The civil society has three representatives on each regional council, representing environment, and recreation and economic actors representing tourism. The civil society also has a member on the Park Board, representing the environmental sector, while the recreational sector and tourism sector has only a member without voting rights.

Although the co-management structure is inclusive of local governments and some civil society actors, we found some dissatisfaction around these membership arrangements. The membership concerns were mainly from the civil society actors that have full representation on the regional councils but only observer status at the Park Board. Moreover, farmers have rights to resources within the park but are not represented in its co-management structure.

We found these claims to be legitimate and they illustrate the membership challenge in a co-management system. It is not clear who should be invited and what powers each member should get in such system. In the case of VNP, farmers are partly dissatisfied by not being members of the regional councils and some civil society actors included on the regional councils are dissatisfied about not being full members of the Park Board. There is obviously no single blueprint for legitimate membership, but these are evidently key issues for any co-management park consideration as they can severely impact the legitimacy of its establishment and operations.

Co-management is essentially about power sharing. The formal actor structure reflects the aim of devolving power from the central to the local. The local governments have a chairman in all regional boards, three out of six members in the regional boards, and four out of seven votes in the Park Board.

Our respondents at all levels appreciated that the co-management model had truly and comprehensively shared power and devolved it to a local level and beyond central government. The system gives the local governments' actors the majority vote on the Park Board and the chair in all the regional councils. The civil society actors have got a formal decision-making power in the system and not only a consultative function as is commonly practiced in other PAs. Furthermore, the Minister is bound to formally endorse the management plan without having any amendment power, given it meets all the legal requirements, and this is seen as a key manifestation of the power sharing and devolution. There is also the notion that the park actors have in general been accountable to the powers devolved to them, an important issue to ensure the legitimacy of VNP's operations.

Another issue related to the actors and their power relations is the funding of VNP's operations. As it is an independent government authority, the bulk of its funding comes directly from the state budget, however, with a legal option for generation of its own incomes from services in the park. This has commonly been in a ratio of circa 80:20 annually with VNP's own incomes having grown in parallel with increased tourism. Funding the park has been subject to bargaining between the central and local governments, perhaps not a surprise given the general tug-of-war on funding between these two levels of government in Iceland on multiple issues. This commonly plays out in local governments asking for more resources than the central government is willing to release. Adding to this resentment is the commonly raised issue of unkept financial promises relating to VNP's establishment, 
frequently raised in the semi-structured interviews. As a part of their initial agreeing to the park and an important carrot for their acceptance of its establishment had been a generous offer by the central government to provide park infrastructure and jobs in the respective jurisdictions. This bargaining resulted in the locations for VNP's regional administrative centres being stated in the legislation, with a central government promise to provide sufficient financial capital for this purpose. The government promises for funding park infrastructure were, however, severely constrained almost immediately after VNP's establishment by the Iceland economic collapse in 2008, which was followed by the austerity plan and severe cuttings in all government spending. There is actually still a backlog in VNP's infrastructure development. The issue of park funding, both to secure sufficient funding and its internal allocation, is truly a significant challenge for their comanagement system. The high level of funding coming directly from the state budget in VNP gives the central government actors great power to influence and steer, albeit not necessarily in a direct manner.

\subsubsection{Actor Complexity and Role Ambiguity}

At first glance, the actor structure of the governance system looks complex (Table 4). It should be kept in mind that the aspiration for being inclusive and sharing power calls for a more complex structure, at least compared to the more traditional top-down and authoritarian governance systems. It is, however, a challenge for designing a comanagement system to ensure that actors responsibilities and their degree of authority are clear. During a smooth ride, this might not be an issue but upon entering more turbulent periods, this becomes a seminal issue.

Table 4. Key actors and their roles in governance of Vatnajökull NP.

\begin{tabular}{|c|c|c|c|}
\hline Level & Actors & Description & Some Important Roles \\
\hline \multirow{3}{*}{ 苞 } & $\begin{array}{l}\text { Ministry for the Environment and } \\
\text { Natural Resources }\end{array}$ & $\begin{array}{l}\text { VNP is an independent government authority, } \\
\text { directly reporting to the Ministry }\end{array}$ & $\begin{array}{c}\text { Appoints the Board } \\
\text { Formalises Director's appointment according } \\
\text { to the Board's recommendation } \\
\text { Financial supervision relative to the state } \\
\text { budget } \\
\text { Overall responsibility }\end{array}$ \\
\hline & Park Board & $\begin{array}{l}\text { Seven board members. Two appointed by the } \\
\text { minister, one from each of the four regional } \\
\text { units, one from environment civil society. Also, } \\
\text { two civil society actors have observer status. }\end{array}$ & $\begin{array}{l}\text { Policy and decision-making } \\
\text { Coordination of regional inputs and creation } \\
\text { of the management plan } \\
\text { Approve the budget and allocate to regions } \\
\text { Harmonise the operation of the four regions }\end{array}$ \\
\hline & Executive Director & The executive director of the park & $\begin{array}{c}\text { Execute decisions and policy, set out in the } \\
\text { management plan } \\
\text { Daily management } \\
\text { Staff } \\
\text { Finance }\end{array}$ \\
\hline \multirow{2}{*}{ 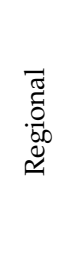 } & Regional committees & $\begin{array}{l}\text { The park is divided into four administrative } \\
\text { regions: north, east, south and west. }\end{array}$ & $\begin{array}{l}\text { Responsible for park management } \\
\text { policy-making within each region } \\
\text { Prepares regional sections of the overall park } \\
\text { management plan }\end{array}$ \\
\hline & Regional park managers & $\begin{array}{l}\text { For each of the four management regions. } \\
\text { Appointed after recommendation from the } \\
\text { regional boards }\end{array}$ & $\begin{array}{l}\text { Responsible for the management activities of } \\
\text { individual regions }\end{array}$ \\
\hline \multirow{4}{*}{ שี } & Local governments & $\begin{array}{l}\text { There are eight local governments that border } \\
\text { the park }\end{array}$ & $\begin{array}{l}\text { Have three members on the regional boards } \\
\text { and four in the Park board }\end{array}$ \\
\hline & Recreational NGOs & A group of NGOs engaged in recreation. & $\begin{array}{l}\text { Members of the regional committee and } \\
\text { observer at the Park Board }\end{array}$ \\
\hline & Environmental NGOs & A group of NGOs engaged in conservation. & Members of the regional board and Park Board \\
\hline & Tourism actors & The regional tourism societies & $\begin{array}{c}\text { Members of the regional committee and } \\
\text { observer at the Park Board }\end{array}$ \\
\hline
\end{tabular}


It was a recurrent theme from our respondents in the semi-structured interviews that the actor structure and the ambiguous definition of their roles and mandates were among the key challenges in VNP's system, although they appreciated its power-sharing aspect. Ambiguity in roles has then manifested differently and was jointly seen as impacting the output legitimacy of the park, undermining its effectiveness.

It was highlighted that during the first years of VNP's operation, this had been less of an issue as most actors were influenced by the high level of input legitimacy, and were thus comfortable with the park and being a part of its governance system. This, however, changed during the development of the park, both simply as time elapsed from its happy beginning but also when many decisions materialised, not least following the development of the first management plan. Many of the informal norms and conventions that had defined some of the coordination between the individual actors during the first years of operation were discarded. This ambiguity in actor roles has impacted the governance system's coordination and its conflict resolution capacity.

In general, the park actors agreed that the co-management system had been effective and capable of resolving the most conflicting issues. This was commonly raised during our semi-structured interviews, regional stakeholder meetings and other interviews. Interviewees appreciated that the devolved and inclusive structure was conducive for settling localised and conflicting issues. In addition, the process around development of the main steering document, the management plan was viewed as conducive to address, discuss and settle the most conflicting issues.

However, what was also raised was that some conflicting issues could become overwhelming and perhaps beyond the capacity of the co-management system to settle. A common theme was the conflict around motorised travel across the Vonarskarð highland landscape, where both the involved local governments and civil society actors have conflicting views on access. This single case of conflict had been impossible to settle with solutions deemed legitimate by the involved actors. That had therefore led to a loss of trust between the actors and amplified the ambiguity of a system wherein the final decision-making power is vested in the co-management system. Such conflicting cases can undermine the otherwise well-functioning co-management system. The obvious solution, we argue, would be to see some sort of independent reconciliation body established outside the park, where such disputes could be settled.

The issue of clarity in roles and degree of authority became a key issue for the park in 2018. It turned out to be overspending on its infrastructure development after significant increases in tourist numbers had led to a need for major investments. This was followed by a period of blame-game between the Park Board and Director on who had the necessary oversight, resulting in external evaluations including the National Audit Office [51]. In the end, the Minister replaced both the Park Director and Board Chairman. This episode clearly illustrated the importance of clarity on the degree of authority among the park actors in the co-management system. This was not an issue of any wrongdoings but rather a case of unclear roles.

This has been one of the key challenges for the VNP model and a key lesson for PA co-management. Although high input legitimacy and trust from the beginning can take a long time to cultivate, there is the necessity to ensure rigid delineation of actor roles and clarity about the degree of authority that each has in the power-shared system.

\section{Conclusions and Implications for Policy}

We find the co-management governance system of VNP to be a solid institutional framework for this large park which has been able tackle very high visitor numbers and emerging tourism pressures, illustrating its capacity to cope with the emerging changes. Our analysis revealed the key design features of the governance system and how the comanagement approach has been instituted and manifests in decision-making. By using a governance system framework, we were able to identify the various governance challenges that shape its performance in multiple ways. 
An important strength of the co-management system is that it facilitates the sharing of power, which is devolved from the central to the local, is inclusive to actors on multiple levels and is well integrated and aligned to the general land-use institutional framework. This has been made possible with park-specific legislation that has been the basis for the creation of multiple, innovative institutions for its coordination and interplay, both internally and externally. The legally binding and strong foundation in the VNP's management plan has proven to be essential to steer and coordinate park management. It is the strategic document for policy and decision-making that has become the glue that binds together and coordinates local, regional and national level interests. This was further leveraged with a high level of legitimacy at the input level, a key-issue which still presides more than a decade after VNP's inception. Some regions demonstrate well how rural development opportunities can be seized locally, something that, however, does not occur automatically, and there is a considerable regional variability in how such economic opportunities have been grasped. Its needs also to be recalled that the assessment provided in the study has a focus on the social aspects of the governance system but did not aim to assess the direct ecological conservation impacts.

The weaknesses of the co-management model relate to its complex actor structure and constraints in defining and delineating the roles and mandates of key actors. This has become especially demanding as the co-management model has redistributed power. Although trust, norms and conventions are important elements of coordination with the co-management system, roles and decision-making mandates need to be clearly defined and determined with respect to the many actors. Most conflicts have been settled within the governance system, but some local issues have become overwhelming for VNP's comanagement system and difficult to settle. This calls for further work to align and adapt the co-management governance system. It has been a strength for VNP to have park-specific legislation and be leveraged as an independent government authority, but in comparison this is a weakness for the other parks that might not be offered such luxury. Being big is surely beneficial when considering tailormade institutional solutions to PAs.

PAs are a major land-use category and current expectations are that their coverage will continue to increase in the future. In Iceland, there are currently plans for expanding a NP model over large tracts of the Central Highlands in a proposed Highlands National Park and, globally, the coming CBD Post 2020-biodiversity goals will set out more ambitious targets for global, area-based conservation. This calls for further studies on governance system diversity and alternative models of governance. Our findings from this study have implications for the ongoing debate on alternative governance models for protected areas, although they also illustrate very well how co-management is context dependent and requires tailormade solutions. Our findings clearly demonstrate that co-management can result in a solid framework, but it does not come as a "one-size-fits-all" solution. This implies a need for diverse approaches for governance which are cognizant of the context and site-specific conditions that they operate within.

That might perhaps become one of the key obstacles for a large-scale rollout of such approaches, as policy-makers at different levels might not have the capacity, interest or available time and resources to develop such approaches, and they would therefore fail to secure the important input legitimacy, which has been among the key factors in VNP's relative success.

Supplementary Materials: The following are available online at https:/ /www.mdpi.com/article/10 $.3390 /$ land10070681/s1, Table S1: The guiding questions in the semi-structured interviews.

Author Contributions: Conceptualisation, data collection, writing, review and editing, J.G.P. and D.M.K. All authors have read and agreed to the published version of the manuscript.

Funding: This research received no external funding.

Institutional Review Board Statement: Not applicable.

Informed Consent Statement: Not applicable. 
Conflicts of Interest: The authors declare no conflict of interest.

\section{References}

1. Leclère, D.; Obersteiner, M.; Barrett, M.; Butchart, S.H.; Chaudhary, A.; De Palma, A.; DeClerck, F.A.; Di Marco, M.; Doelman, J.C.; Dürauer, M.; et al. Bending the curve of terrestrial biodiversity needs an integrated strategy. Nature 2020, 585, 551-556.

2. Ward, M.; Saura, S.; Williams, B.; Ramírez-Delgado, J.P.; Arafeh-Dalmau, N.; Allan, J.R.; Venter, O.; Dubois, G.; Watson, J.E. Just ten percent of the global terrestrial protected area network is structurally connected via intact land. Nat. Commun. 2020, 11, 4563. [CrossRef] [PubMed]

3. Watson, J.E.M.; Dudley, N.; Segan, D.B.; Hockings, M. The performance and potential of protected areas. Nature 2014, 515, 67-73. [CrossRef]

4. Borrini-Feyerabend, G.; Dudley, N.; Jaeger, T.; Lassen, B.; Pathak Broome, N.; Phillips, A.; Sandwith, T. Governance of Protected Areas: From Understanding to Action; IUCN: Gland, Switserland, 2013.

5. Eklund, J.; Cabeza, M. Quality of governance and effectiveness of protected areas: Crucial concepts for conservation planning. Ann. N. Y. Acad. Sci. 2017, 1399, 27-41. [CrossRef]

6. Carlsson, L.; Berkes, F. Co-management: Concepts and methodological implications. J. Environ. Manag. 2005, 75, 65-76. [CrossRef]

7. Fischer, A.; Wakjira, D.T.; Weldesemaet, Y.T.; Ashenafi, Z.T. On the interplay of actors in the co-management of natural resourcesA dynamic perspective. World Dev. 2014, 64, 158-168. [CrossRef]

8. Borrini-Feyerabend, G.; Farvar, M.T.; Nguinguiri, J.C.; Ndangang, V.A. Co-Management of Natural Resources: Organising, Negotiating and Learning-by-Doing; GTZ and IUCN: Heidelberg, Germany, 2007.

9. Fedreheim, G.E.; Blanco, E. Co-management of protected areas to alleviate conservation conflicts: Experiences in norway. Int. J. Commons 2017, 11, 754-773. [CrossRef]

10. Hovik, S.; Hongslo, E. Balancing local interests and national conservation obligations in nature protection. The case of local management boards in norway. J. Environ. Plann. Manag. 2017, 60, 708-724. [CrossRef]

11. Plummer, R. The adaptive co-management process: An initial synthesis of representative models and influential variables. Ecol. Soc. 2009, 14, 24. [CrossRef]

12. Evans, L.; Cherrett, N.; Pemsl, D. Assessing the impact of fisheries co-management interventions in developing countries: A meta-analysis. J. Environ. Manag. 2011, 92, 1938-1949. [CrossRef]

13. Lockwood, M. Good governance for terrestrial protected areas: A framework, principles and performance outcomes. J. Environ. Manag. 2010, 91, 754-766. [CrossRef]

14. Petursson, J.G.; Vedeld, P. Rhetoric and reality in protected area governance: Institutional change under different conservation discourses in mount elgon national park, uganda. Ecol. Econ. 2017, 131, 166-177. [CrossRef]

15. Borrini, G.; Kothari, A.; Oviedo, G. Indigenous and Local Communities and Protected Areas. Towards Equity and Enhanced Conservation; IUCN: Gland, Switerland, 2004.

16. Cundill, G.; Thondhlana, G.; Sisitka, L.; Shackleton, S.; Blore, M. Land claims and the pursuit of co-management on four protected areas in south africa. Land Use Policy 2013, 35, 171-178. [CrossRef]

17. Ribot, J.C.; Agrawal, A.; Larson, A.M. Recentralizing while decentralizing: How national governments reappropriate forest resources. World Dev. 2006, 34, 1864-1886. [CrossRef]

18. Hutton, J.; Adams, W.M.; Murombedzi, J.C. Back to the barriers? Changing narratives in biodiversity conservation. Forum Dev. Stud. 2005, 32, 341-370. [CrossRef]

19. Child, B.A. Parks in transition: Adapting to a changing world. Oryx 2014, 48, 469-470. [CrossRef]

20. Spenceley, A. Tourism and protected areas: Comparing the 2003 and 2014 iucn world parks congress. Tour. Hosp. Res. 2017, 17, 8-23. [CrossRef]

21. Sandwith, T.; Enkerlin, E.; MacKinnon, K.; Allen, D.; Andrade, A.; Badman, T.; Brooks, T.; Bueno, P.; Campbell, K.; Ervin, J.; et al. The promise of sydney: An editorial essay. Parks 2013, 20, 7-18. [CrossRef]

22. Jentoft, S. Legitimacy and disappointment in fisheries management. Mar. Policy 2000, 24, 141-148. [CrossRef]

23. Berkes, F. Evolution of co-management: Role of knowledge generation, bridging organizations and social learning. J. Environ. Manag. 2009, 90, 1692-1702. [CrossRef]

24. Stenseke, M. Local participation in cultural landscape maintenance: Lessons from sweden. Land Use Policy 2009, 26, 214-223. [CrossRef]

25. Petursson, J.G.; Thorvardardottir, G.; Crofts, R. Developing iceland's protected areas: Taking stock and looking ahead. Parks 2016, 22, 13-24. [CrossRef]

26. Ostrom, E. Governing the Commons: The Evolution of Institutions for Collective Action; Cambridge University Press: Cambridge, UK; New York, NY, USA, 1990; p. xviii. 280p.

27. Ostrom, E. Understanding Institutional Diversity; Princeton University Press: Princeton, NJ, USA, 2005.

28. Vatn, A. Institutions and the Environment; Edward Elgar: Cheltenham, UK, 2005.

29. Ostrom, E. A general framework for analyzing sustainability of social-ecological systems. Science 2009, 325, 419-422. [CrossRef] [PubMed]

30. Vatn, A. Environmental Governance; Institutions, Policies and Actions; Edward Elgar: Celtenham, UK, 2015.

31. Young, O.R. The Institutional Dimensions of Environmental Change: Fit, Interplay, and Scale; MIT Press: Cambridge, MA, USA, 2002. 
32. Scott, W.R. Institutions and Organizations; Sage Publications: Newbury Park, CA, USA, 1995.

33. Pomeroy, R.S.; Berkes, F. Two to tango: The role of government in fisheries co-management. Mar. Policy 1997, $21,465-480$. [CrossRef]

34. Arts, B. Non-State Actors in Global Governance: Three Faces of Power; Max-Planck-Projektgruppe Recht der Gemeinschaftsgüter: Bonn, Germany, 2003.

35. Giddens, A. The Constitution of Society: Outline of the Theory of Structuration; Polity Press: Cambridge, UK, 1984; p. xxxvii, 402p.

36. Backstrand, K. Multi-stakeholder partnerships for sustainable development: Rethinking legitimacy, accountability and effectiveness. Eur. Environ. 2006, 16, 290-306. [CrossRef]

37. Brown, K. Integrating conservation and development: A case of institutional misfit. Front. Ecol. Environ. 2003, 1, 479-487. [CrossRef]

38. Vatn, A.; Vedeld, P. Fit, interplay, and scale: A diagnosis. Ecol. Soc. 2012, 17, 12. [CrossRef]

39. Baldursson, S.; Gudnason, J.; Hannesdottir, H.; Thordarson, T. Nomination of Vatnajökull National Park for Inclusion in the World Heritage List; Vatnajökull National Park: Reykjavik, Iceland, 2018.

40. Umhverfisstofnun. The 2021 Annual Report of The Icelandic Environment Agency; Iceland Environment Agency: Reykjavik, Iceland, 2021.

41. OECD. "Iceland"; OECD Publishing: Paris, France, 2020.

42. Siltanen, J. Economic Impact of Iceland's Protected Areas and Nature-Based Tourism Sites; Institute of Economic Studies: Reykjavik, Iceland, 2018.

43. Solnes, V. Administrative committee clarifying land ownership. The icelandic wasteland commission. Nord. Adm. J. 2017, 94, 59-74.

44. Gunnarsson, V. Orðræða um Stofnun Vatnajökulspjóðgarðs. Ferðamennska, Sjálfbærni og Samfélag. Master’s Thesis, Univerisity of Iceland, Reykjavík, Iceland, 2010.

45. Feingold, M. The Political Ecology of Protected Areas: The Case of Vatnajökull National Park. Master's Thesis, University of Iceland, Reykjavik, Iceland, 2021.

46. Petursson, J.G.; Ingolfsdottir, G.; Kristofersson, D.M. Endurskoðun á Stjórnfyrirkomulagi Vatnajökulspjóðgarðs; Reykjavik, Iceland. 2013. Available online: https://rafhladan.is/bitstream/handle/10802/24252/vatnajokull_lokaskyrsla-180713.pdf? sequence $=1$ (accessed on 28 June 2021).

47. Benediktsson, K.; Thorvardardottir, G. Frozen opportunities? Local communities and the establishment of vatnajökull national park iceland. In Mountains of Northern Europe: Conservation, Management, People and Nature; Thompson, D.B.A., Price, M.F., Galbraith, C.A., Eds.; Scottish Heritage: Edinburgh, UK, 2005; pp. 333-347.

48. Gunnarsson, S.B. Vatnajökulspjóðgarður (vatnajökull national park). Glettingur 2007, 44, 26-30.

49. Saeporsdottir, A.D.; Hall, C.M.; Wendt, M. Overtourism in iceland: Fantasy or reality? Sustainability 2020, 12, 7375. [CrossRef]

50. Ingólfsdóttir, A.I.; Árnason, T.; Siltanen, J.; Jóhannesson, H. Náttúruvernd og Byggðapróun: Hrif Verndarsvæða á Grannbyggðir; Hagfræðistofnun Háskóla Íslands: Reykjavík, Iceland, 2019.

51. National Audit Office. Vatnajökulspjóđgarður. Ríkisendurskoðun, Skýrsla til Alpingis (Vatnajökull National Park. National Audit Office, Report to the Parliament); National Audit Office: Reykjavík, Iceland, 2019. 